\title{
Invoking Alphonse: The founder figure as a historical resource for organizational identity work ${ }^{1}$
}

\author{
Joëlle Basque \\ Research Fellow \\ joelle.basque@hec.ca \\ 514-340-6000 ext. 2974 \\ Ann Langley \\ Professor \\ ann.langley@hec.ca \\ 514-340-7748 \\ HEC Montréal \\ 3000 Chemin de la Côte-Sainte-Catherine \\ Montréal, Qc, Canada \\ H3T 2A7
}

Final Version

May 2018

\section{Accepted for Publication in Organization Studies}

\footnotetext{
${ }^{1}$ We thank three anonymous reviews and Editor Roy Suddaby for advice on earlier versions of the paper. We also thank Nora Meziani, Linda Putnam, Eero Vaara and participants in the 2016 Colloquium of the European Group for Organizational Studies as well as other presentations with various audiences for their commentary. Finally, we thank Guy Bélanger, historian of the Société Historique Desjardins for comments on an earlier version.
} 


\title{
Invoking Alphonse: The founder figure as a historical resource for organizational identity work
}

\begin{abstract}
There has been growing interest in the rhetorical use of history to express organizational identity claims. Yet, the evolving role of the founder figure in managerial accounts has not so far received specific attention. In this study, we examine how the founder figure is used to articulate, enact, stretch, preserve or refresh expressions of organizational identity, drawing on an 80-year magazine archive of a financial cooperative. We identify five modes of founder invocation, and show how distance from founding events leads to increasing abstraction in linkages between the founder and organizational identity claims. The paper offers a dynamic perspective on the mobilization of the founder in organizational identity construction as well as an understanding of how and why founders may remain established identity markers long after their demise.
\end{abstract}

Key words: rhetorical history, founders, organizational identity work, cooperatives 
Today, in 2012, which has been declared the International Year of Cooperatives by the United Nations, it seems especially important and relevant to revisit the thoughts of Alphonse Desjardins. This is all the more true as our current context is in some important respects reminiscent of the one in which the first caisses [credit union branches] were founded (...).

I also had a very personal reason for putting together this book. I always like to lay out principles and signposts so that in the heat of the action, I never lose sight of what matters most. At Desjardins, the vision of our founder must remain one of our main sources of guidance, along with our mission, our cooperative values, and the strategic orientations that we adopt together.

Monique Leroux, President of the Desjardins Group, Introduction to Alphonse Desjardins: A Vision for Today’s World, Les Éditions Dorimène, 2012.

In the quotation above, Monique Leroux, President of the Desjardins Group, a financial services cooperative with over 47,000 employees in 2016, invokes the vision of the founder Alphonse Desjardins (1854-1920) as one of her “main sources of guidance” even though he died 92 years prior to the publication of the book of quotations she authored in his honor, and even though the small cooperative he founded in 1900 has evolved to become a complex financial institution. Yet, although no longer of this world, Alphonse Desjardins is still a shadow presence inhabiting the discourse of its senior managers.

The persistence of references to the founder is clearly not limited to this organization. For example, Tim Cook (CEO of Apple) noted in a 2016 media interview (Balakrishnan, 2016): "From my point of view, Steve [Jobs, Apple's deceased founder] - his spirit will always be the DNA of the company. He embodied who we are. It was his vision that Apple should make the best products, and it was his vision that they should enrich people's lives. Lots of other things will change with Apple, but that will never change.”

In other words, in some cases, an organization's founders can live on long after their demise, haunting the discourses of their successors, and participating in the construction of organizational identity, defined by Albert and Whetten (1985) as those characteristics of the organization taken by members to be central, distinctive and enduring. Indeed, Cook's reference 
above to Steve Jobs as "embodying who we are," as the "DNA" of Apple, with a vision of making the "best" products that "enrich people's lives," and as something that "will never change" exemplifies the three definitional elements of organizational identity in microcosm.

Recent research has seen a growing interest in the use of history in organizational identity construction (Anteby \& Molnár, 2012; Schultz \& Hernes, 2013; Suddaby, Foster, \& Quinn Trank, 2010; Zundel, Holt, \& Popp, 2016). As suggested in this literature, founders and their memory traces offer ample material for mobilization by successors. For example, Schultz and Hernes (2013) showed how the LEGO corporation drew on stories, texts and artifacts associated with the founder to reformulate LEGO’s identity. Maclean, Harvey, Sillince and Golant (2014) showed how leaders at Proctor \& Gamble mobilized founder memories to build shared ideology. Jaskiewicz, Combs and Rau (2015) found that stories of entrepreneurial resilience dating back to founding were common among centuries old German wineries. Histories of founders appear to be particularly important identity resources for family firms (Blombäck \& Brunninge, 2013). At the same time, as Rowlinson and Hassard (1993) illustrated in their deconstruction of the founding myth of Cadbury's, founders themselves are reciprocally (re)constructed through historical accounts that may selectively orient recipients' understandings. Such interpretations may shift over time, as later managers reinterpret history to realign a desired future with a reconstructed past (Gioia, Corley, \& Fabbri, 2002; Maclean et al., 2014).

Yet, although founders' memories have been recognized as an important resource in identity construction, few studies have focused attention on how the nature of a founder's presence in organizational communications evolves over long periods, and how this may be linked to organizational identity. In this paper, we draw on a unique archival database constituted by the internal magazine of the Desjardins Group published continuously for 80 years to examine 
these issues. Specifically, we ask: How is the founder figure invoked in organizational communications to construct organizational identity through changing times?

Based on our analysis, we identify five modes of invocation in organizational discourse (i.e., references to the founder for a strategic purpose). We suggest that each of these modes plays complementary roles in efforts to gain support from organization members, and that each has importance for organizational identity construction but in different ways. Second, we show how links between the founder figure and organizational identity change over time, becoming increasingly abstract and allusive. We thus contribute to the literature on the uses of the past by showing the various ways through which founder invocation promotes continuity in the expression of organizational identity over long periods, despite major transformations in the organization's context and orientation. We begin by reviewing the literature on history, organizational identity and the role of the founder prior to presenting our study.

\section{Rhetorical History, Organizational Identity Work and the Role of the Founder Rhetorical history and organizational identity work}

The "rhetorical history" perspective that inspired this paper focuses on "the strategic use of the past as a persuasive strategy to manage key stakeholders of the firm" (Suddaby et al., 2010, p. 157). From this perspective, traces of deceased founders in current managerial discourses are viewed as directed towards influencing contemporary stakeholders, rather than as objective reflections of an immutable heritage. This perspective resonates with business history research on the role of historical narratives in constructing identity (Mordhorst, 2008, 2014; Rowlinson \& Hassard, 1993) as well as with management literature on the uses of history (Anteby \& Molnár, 2012; Foster, Suddaby, Minkus, \& Wiebe, 2011; Hatch \& Schultz, 2017). 
Specifically, the rhetorical history literature has focused on the use of speeches, reports or newsletters (Anteby \& Molnár, 2012), corporate museums (Nissley \& Casey, 2002; Rowlinson, 2002), corporate histories (Rowlinson \& Hassard, 1993), and other historical materials to achieve different ends. Suddaby et al. (2010) discuss three strategic purposes for uses of history: conferring legitimacy, conferring identity, and facilitating strategic change. Brunninge (2009) refers to five uses: "scientific" (establishing facts), "existential” (anchoring in origins), "moral” (rehabilitation of forgotten dimensions), "ideological" (legitimation of proposed actions), and "non-use" (refraining from historical references to avoid interrogation of proposed actions).

Central among rhetorical history studies for the purposes of this paper are those that have focused on how managers draw on history to suggest organizational identity referents, or to perform “organizational identity work” (Kreiner \& Murphy, 2016; Suddaby, Foster, \& Quinn Trank, 2016). The notion of "identity work" was initially developed at the individual level, and was defined by Sveningsson and Alvesson (2003) as "effort involved in "forming, repairing, maintaining, strengthening or revising the constructions [of identity] that are productive of a sense of coherence and distinctiveness." (p.1165). Moving to the organizational level, we define “organizational identity work" as "effort engaged in by organization members individually or collectively to form, repair, maintain, strengthen or in other ways influence understandings of the central, distinctive and enduring characteristics of a specific organization."

Our definition of organizational identity work thus builds on Albert and Whetten's (1985) definition of organizational identity, while emphasizing the role of agency in identity construction. Indeed, for rhetorical history studies, we argue that the notion of "organizational identity work" has distinct advantages (see also Suddaby et al., 2016). First, as Kreiner and Murphy (2016) note, it dissolves debates around whether "enduringness" or "continuity" is a 
necessary characteristic of organizational identity (Gioia, Patvardhan, Hamilton, \& Corley, 2013) by focusing on the means by which members work to establish continuity or discontinuity in their discourse or behaviors. Second, the notion of "organizational identity work" avoids assumptions of sharedness and clarity inherent to much of the literature (Gioia et al., 2013). As Watson (2016) indicates, the focus on "organizational identity work" draws attention to what people do to instill or reorient conceptions of identity. The concept is thus useful to consider how managerial communications such as newsletters promote constructions of organizational identity, without assuming that these are shared or immutable.

Our usage here of the term "organizational identity work" is similar to that of Anteby and Molnár (2012) and Suddaby et al. (2016) who both employ it to refer to the way in which an organizations' top managers mobilize discursive elements in their communications to promote conceptions of identity likely to resonate with audiences. For example, Anteby and Molnàr (2012) showed how managers of an aeronautics firm constructed a nationalist identity in internal employee bulletins by minimizing ("forgetting”) contradictory elements from the past such as the significant role of foreign partners. Suddaby et al. (2016) use the term "re-membering" to describe how rhetorical uses of history draw on and orient collective memories to establish organizational identity and to stimulate identification (member-ship) from stakeholders.

Similarly, while not always referring to the notion of "organizational identity work" per se, other studies have examined how managers use such historical referents in their organizational identity constructions. For example, Chreim (2005) examined shareholder messages for a Canadian bank over 20 years, showing how identity labels were maintained even as meanings changed (see also Gioia, Schultz, \& Corley, 2000). Golant et al. (2014) further documented how the identity-defining concept of "thoroughness" was successfully adapted by 
managers at Procter \& Gamble to mask problems resulting from past actions. These studies do not, however, focus explicitly on founders. We now consider some studies that do.

\section{Founders as symbolic resources for organizational identity work}

The symbolic importance of founders to organizational identity construction has been recognized in several previous studies (Blombäck \& Brunninge, 2013; Jaskiewicz et al., 2015; Maclean et al., 2014). However, little research has examined the evolution of the use of the founder figure in relation to organizational identity over longer periods of time, as we do here. Nevertheless, two particular studies stand out in this area.

First, Schultz and Hernes (2013) compared two identity redefinition initiatives at LEGO. They show how in the second initiative, managers drew on diverse memory cues (oral, textual and material) relating to the founder, notably by resurrecting his motto "Only the best is good enough,” and by retelling orally transmitted stories that illustrated his concern with quality and excellence. This enabled LEGO to reach beyond the incremental adjustments of earlier identity exercises that drew on the more recent past and used a narrower range of memory traces. In another study, Hatch and Schultz (2017) showed how Carlsberg revived a slogan "Semper Ardens” associated with the founder's son twice, once to develop an artisanal beer brand, and once as the centerpiece of a new identity statement. They argue that the rich historical grounding and emotional connotations of the slogan (carved on the entrance of Carlsberg's original head office building) contributed to a sense of authenticity that had value for those involved.

Both these studies show the power of historical references to the founder in managerial efforts at organizational identity definition. Yet, although they offer valuable insights, their methods do not enable them to track the evolution in associations between the founder and 
organizational identity claims over long periods, a somewhat different though complementary objective that requires different kinds of data as we now describe.

\section{Methods}

\section{Research context and data}

The organization studied here is the Desjardins Group (in French, the Mouvement Desjardins), a Quebec-based cooperative financial institution founded in 1900 by Alphonse Desjardins. Alphonse was raised in a poor family, and grew up to become a journalist. During his life, he became concerned by the problem of loansharking, which in his view contributed to maintaining his fellow French Canadians in poverty. He discovered the cooperative movement developing in Europe while working in the Canadian Parliament as a stenographer, and began encouraging the foundation of small savings and loans cooperatives (called "Caisses populaires”). He began in his hometown of Lévis, and subsequently extended his work from Quebec to Ontario. He founded 163 caisses during his lifetime (Poulin \& Tremblay, 2005, p. 6). Each cooperative was associated with a parish, and the Catholic clergy was deeply involved in managing the caisses, seen as non-profit community organizations dedicated to the economic emancipation of working class French Canadians in a society dominated by Anglo-Saxon economic interests. After his death in 1920, the movement continued to grow through the actions of his successors, supported by the founder's wife Dorimène, who survived him by 12 years. Regional Unions were developed, to offer support to the individual caisses.

After a slow start, the recovery following the financial crisis of 1929 gave second wind to the movement, which grew rapidly over the years to become a major financial institution. In 1982 Desjardins had 1465 caisses offering a broad range of financial services (Poulin \& 
Tremblay, 2005, p. 68). According to its website ${ }^{2}$, in 2016, Desjardins had $\$ 258.4$ billion in assets, over 7 million members and clients, 47,655 employees and 4,571 elected officers.

Our main source of data for this study is the Revue Desjardins, ${ }^{3}$ a magazine intended for officers, managers and employees of the caisses. Officers are not employees, but members of the cooperative who are democratically elected to the Boards and committees of each caisse. In other words, they represent the users. ${ }^{\text {s }}$ The Revue was launched in 1935 as an organ of the "Fédération de Québec des Unions Régionales des Caisses Populaires Desjardins” (hereafter called the Federation) that had been created in 1932 by the four Regional Unions existing at that time with a government subsidy of $\$ 20,000$ to support inspections and other coordinating activities. Articles in the Revue Desjardins were written by leaders and members of Desjardins between 1935 and 2015. From 4 to 10 issues were published per year for 80 years (606 documents).

Internal newsletters are useful data sources to study the evolution of managerial discourses (Anteby \& Molnár, 2012; Chreim, 2002), because they "reflect managerial viewpoints” (Chreim, 2002, p. 1127) even when not entirely written by managers. As suggested by Anteby and Molnar (2012), such sources are also prime sites for organizational identity work by executives because they are widely distributed to an audience whose appropriation of organizational goals and meanings is important to future development.

Of course, while significant, the Revue Desjardins is not the only site for organizational identity work, and as a mnemonic, it underplays some events and emphasizes others (Anteby \& Molnár, 2012). Thus, although our main interest is in how the founder is drawn on in this source, we also collected other archival materials to better understand the context. These include

\footnotetext{
${ }^{2}$ https://www.desjardins.com/ca/about-us/desjardins/who-we-are/quick-facts/index.jsp (consulted July 25th 2017)

${ }^{3}$ Digitized data provided by the Observatoire international des coopératives de service financier of the Alphonse and Dorimène Desjardins International Institute for Cooperatives: http://observatoire.coopfinance.hec.ca/fr/home.html. The Revue was initially named La Caisse Populaire Desjardins but became the Revue Desjardins as of 1941.
} 
corporate histories and other books (Lévesque, 1997; Poulin, 1998; Poulin \& Tremblay, 2005;

Rousseau \& Levasseur, 1995), newspaper articles, and government documents.

\section{Data analysis}

The analysis of the extensive corpus was carried out in two steps. The first step (“decontextualization”) involved identifying and coding references to the founder in the text to understand the roles these might play. In the second step ("recontextualization”) we examined patterns in these references over time, and related these to the historical context.

\section{Step 1: Decontextualization: Identifying and characterizing types of founder invocations.}

We used the automatic coding function of Atlas.ti to identify all references to the founder, using words associated with him identified during initial manual exploration (i.e., founder, Commander, ${ }^{4}$ Alphonse, Dorimène). After cleaning to remove erroneous hits, over 4800 references remained. These included text associating the founder's name with various themes, citations of his words, and visual representations. Through iterative coding phases, we identified two broad categories of uses of the founder that we called evocation and invocation. Evocation is a reference to the founder that has no obvious purpose other than as a label (e.g., for a building) or historical fact. These references (about 2500) were not considered further. The second category called invocation is more central to our research because it implies the use of the founder figure to achieve something through associations in the text. We identified the five types of invocation illustrated in Table 1. After refining the definition of codes, a second coder independently coded $10 \%$ of the quotations to check for reliability. Levels of agreement ranged from $87 \%$ to $95 \%$ depending on the code. We then developed graphs to examine the evolution of

\footnotetext{
${ }^{4}$ Alphonse Desjardins had the religious title of “Commander” of a sacred order, and this label was often used to refer to him, particularly in the early years of the Revue Desjardins.
} 
different types of invocation across time (see Figure 1). We now briefly define these five types of invocation. These will be explained and illustrated in further detail in the findings section.

\section{Insert Table 1 here}

The first and most frequent type we call existential invocation (561 quotations). It occurs when the founder is invoked as a direct expression of organizational identity by referring explicitly to the mission and values of the organization, usually its cooperative dimension. The other four types of invocation link the founder in different ways to organizational action. Imperative invocations (211 quotations) call on Alphonse as an authority to exhort others to action, in the form of a "command" that appears to come from the founder himself. Justificatory invocations (503 quotations) call on the founder's words or ideas to legitimate an ongoing course of action by showing how it serves Desjardins' mission as the founder saw it. Finally, the last two forms of invocation are less frequent but significant because of their relationship with organizational change. Conservative invocations (45 quotations) call on the founder to argue for the maintenance of the status quo in the face of pressures for change. In contrast, progressive invocations (79 quotations) call on the founder's name to advocate in favor of renewal or reorientation, by distancing from the past or by presenting change as in accordance with the founder's heritage or persona.

Note that while organizational identity work may seem most obviously associated with "existential" invocation, the other four forms of invocation are also imbued with identity elements. For example, the conservative invocation illustrated in Table 1 refers to the need to maintain "cooperative principles," and the progressive invocation speaks of renewing "who we are.” In the findings section, we elaborate on the specific relations of each mode with identity. 


\section{Step 2: Recontextualization: Tracing patterns in founder-related identity work over time}

The second step in our analysis involved recontextualizing the coded segments within the corpus to understand how organizational identity work is linked to the founder over time. To achieve this, we first grouped quotations according to epochs associated with organizational leaders. In parallel with this, using complementary sources, we identified key events and trends in the history of Desjardins that might have relevance to understanding shifts in the way the founder's name was invoked in relation to organizational identity. Table 2 offers a brief overview of epochs in the history of Desjardins, focusing in particular on major initiatives associated with different leaders.

After examining the evolution of invocations across epochs, we decided to focus the analysis in this paper on key contrasts between two broad eras of Desjardins' history that we call the Foundational Era (1935-1969) and the Modern Era (1970-2015) (see Table 2). We chose 1969 as an analytical breakpoint because it reflects the most palpable shift in the content and style of invocations in the Revue Desjardins as we will show in the findings section.

The breakpoint chosen also coincides with the death in 1969 of Cyrille Vaillancourt who was successively President, Manager and Director General of the Federation created to coordinate activities among the caisses and Regional Unions. Vaillancourt founded the Revue Desjardins, and signed articles in almost every issue until volume 35, no. 1 (1969), setting the tone for communications between the Federation and the officers and managers of the caisses. Although the shift in modes of invocation is not instantaneous or entirely pure, it is quite striking, and there is little doubt that Vaillancourt's dominating presence for the first 35 years is significant and related to this phenomenon.

Insert Table 2 here 
It should be noted that the 1960s were also the scene of profound transformations in Quebec society (known as the "quiet revolution") involving the secularization of Quebec institutions of education and health care, formerly under the tutelage of the Catholic Church. The slogan "Maîtres chez nous” (Masters in our own house) used in the 1962 Quebec election by the liberal party was associated with this movement and symbolized its drive to increase Quebecers' control over their own destiny, reducing the influence of the Church and countering the domination of English Canadian interests over business and industry. These trends are also reflected in the Revue Desjardins.

\section{Findings: Founder Invocation and Organizational Identity Work}

In the findings, we revisit in more detail the five modes of invocation introduced above and their links to organizational identity. As mentioned, we observe a palpable shift in the modes, content and form of invocations between the Foundational and Modern Eras. We now describe the nature of these differences. Table 3 summarizes our main observations.

\section{Insert Table 3 here}

We begin by examining how the nature of existential invocations shift across eras, and then examine how other forms of invocation play into this shift. We complete the analysis by revealing the increasing level of abstraction in founder invocations across types. As suggested in Table 3, invocations begin as very literal in the Foundational Era (i.e., grounded in the founder's exact words) and become more allusive in the Modern Era (when the name and image of the founder become a shorthand symbol for the organization's identity). 


\section{Existential invocations: Articulating the Cooperative identity}

The election to the presidency brought us towards the future. But the future is always built along with pride in our roots and our history. For me, Alphonse Desjardins was the greatest entrepreneur, the greatest financier and the greatest cooperator in Canada. His model of a Caisse close to the people is still a reality. (...)

Desjardins has a soul: Cooperation. This is very precious, because beyond our professional occupation, we are motivated by deep values. (speech by Monique Leroux on her election to the presidency, Revue Desjardins, 74(2), 2008, p.11-12).

As mentioned above, existential invocations are citations of the founder that relate him directly to some expression of the mission, values and identity of Desjardins. They thus serve to articulate that identity. As shown in Figure 1, this is the most frequent form of invocation in the Revue Desjardins. Existential invocations are continuously present over time, though more intense in the Foundational Era (65\% of existential invocations occur in this period) than in the Modern Era, roughly reflecting the overall total of invocations over time. In general, existential invocations not only link the founder to mission, values and identity, but they also express pride in these values, and glorify members' commitment to them.

In existential invocations, one significant organizational identity theme is continuously associated with the founder as central, distinctive and enduring: this is "Cooperation" (i.e., Desjardins as a "Cooperative”). This theme is reflected in the quotations of Table 1 and above.

To re-emphasize this ongoing association, we provide two further extended quotations in Table 4, one from the Foundational Era (first article in the first issue of the Revue Desjardins) and one from the Modern Era (an interview with President Monique Leroux in 2011). Both quotations clearly express cooperation as an identity theme closely linked to the founder.

Insert Table 4 here

The insistence on the centrality and distinctiveness of "Cooperation” as an organizational identity theme and the drive to promote it in line with the founder's ideas is thus consistent 
across time. However, as Gioia et al. (2000, p. 64) point out, while identity labels often stay the same over time, their meanings may change. In other words, the enduring reference to “cooperation” does not necessarily imply stable meanings, and this is certainly the case at Desjardins. By examining existential invocations for the different eras at Desjardins, we can see not only how the construction of the cooperative identity changed over time, but also how its linkage with the founder is reconstructed in the text of the Revue Desjardins.

Indeed in the two quotations above from different eras, we see a subtle difference in the way Cooperation as an identity element is qualified. In the first quotation it is described as a “doctrine” that needs to be "propagated" across the province. In the second from 2011, it is described as a "distinction" that needs to be made "tangible and concrete" noting that "words are not enough,” and implying that more needs to be done to bring the claim of distinction to life. The use of the two words "doctrine” and "distinction” in the two quotations are not idiosyncratic. Cooperation is in fact consistently referred to as a "doctrine” during the Foundational Era (the word appears 31 times in invocations of Alphonse Desjardins in this period and almost never after that). Moreover, the founder's own writings are referred to consistently as the source of the doctrine. In contrast, the term "distinction" or sometimes "difference" as a qualification for the cooperative identity first emerges in 1987 and subsequently becomes a consistent theme in the Revue Desjardins in the Modern Era, and more particularly in the last two decades.

The reference to “doctrine” vs. "distinction” reveals different ways of conceiving the content of the cooperative identity and its relation to the founder. As a “doctrine” deeply embedded in Alphonse's words, cooperation has highly specific literal meanings, referring to a number of different elements associated with the Caisses populaires at the "core" of the Cooperative identity, and seen as fixed and immutable. These include democratic structures 
where caisse members have equal say in decisions, the need to restrict membership of the caisses to the local parish where people know each other and can judge the moral value of potential borrowers, the need to educate members about the value of savings and the dangers of frivolous spending, and an overall understanding that if all these elements are in place, then the cooperative system will lead to economic, social and moral benefits for the entire community. Table 5 illustrates these four elements based on existential invocations of the Foundational Era.

\section{Insert Table 5 here}

A "cooperative distinction," in contrast, is something less precise. Although it certainly incorporates broad values associated with democracy, community solidarity, education and economic development as embedded in the doctrine (see for example the right-hand quotation in Table 4 and Table 1), the notion of distinction does not imply the quasi-religious application of a pre-defined recipe in quite the same way as the notion of "doctrine." Cooperation in this sense has acquired more "interpretive flexibility” (Pinch \& Bijker, 1984) even as it is used to express continuity in organizational identity over time.

Note, also, that the notion of cooperation as a "distinction" implies some notion of an identity struggle: of a need to maintain a distinctiveness that is potentially fragile, and of finding ways to make it real (see Table 4). For example, in 1997, a whole issue of the Revue Desjardins is dedicated to "Awakening the cooperator in you" with the editor introducing the topic as follows, "With the centenary of Desjardins in view, we are asking ourselves what makes up our cooperative distinction and how to make it more alive, more visible more concrete.”

Alban d'Amours (President 2000-2008) introduces another issue with an article entitled, "Achieving the cooperative distinction of the caisses and the Movement: Everyone's business."

"To help his compatriots meet their financial needs, Alphonse Desjardins privileged the cooperative formula.. (...) 
The vision we have given ourselves at the scale of the Movement for 2003-2005, as well as the first of our major strategic orientations affirms clearly that the cooperative distinction is still at the heart of all our objectives and our actions." (Alban d'Amours, Revue Desjardins, 68(4), 2002, p. 4)

What is not mentioned in this quote is that the key distinction that is implicitly or explicitly being claimed is that of not being a bank. Indeed, the label "bank" is eschewed throughout Desjardins' history, even as its operations have become closer to those of banks, and even as its competitors are increasingly banks, as recognized in the following extract from 1998.

"With time, the playing fields of the caisses and banks began to overlap, so that they are on the exact same territory. From that time on, it became more arduous to define the cooperative distinction; but this distinction exists, and we need to better understand it and intensify its development to make it into a true competitive advantage." (Bertrand Laferrière, Revue Desjardins, 65(3), 1998, p.15).

Note in this particular quotation the rather ironic slippage from a social value-based notion of distinction towards one that is more instrumental: i.e., cooperation as competitive advantage. References to competitive advantage do enter into the discourses in the Revue Desjardins, but this is often implicit rather than explicit. More commonly, the emphasis is on cooperative identity and values, those that the key audience of the Revue Desjardins, i.e., the Officers of the Caisses (i.e., active “members” who serve in volunteer administrative roles) are likely to hold dear for their own sake, that they associate with the founder and that sustains their commitment. Nevertheless, the nature of these values are subject to some reinterpretation. We show in later sections dealing with other forms of invocation the ways in which such reinterpretation may typically occur. Prior to examining this however, we turn back to the Foundational era to see how the earlier “doctrinal” version of Cooperative identity was mobilized to orient action.

\section{Imperative invocations: Enacting the Cooperative "doctrine” in the Foundational Era}

To be and to remain worthy of his task, every good officer, every good manager, every good employee must be impregnated, to the marrow, with the spirit of our founder. (...)Then, make sure you become informed more and more and better and better about the 
oeuvre of the Caisses. “Open Letter,” Louis Arneau, Revue Desjardins, 12(2), 1946, p. 34.

While existential invocations offer statements of organizational identity (who we are), all other types including imperative invocations are more related to action (what we are doing). In contrast with existential invocations, imperative invocations are exclusive to the Foundational Era, and are written in such a way as to command action in the founder's name, serving to enact the organizational identity elements constituting the Cooperative identity as "doctrine" to be followed with diligence and detail. They reach beyond simply describing the Cooperative identity (as in existential invocations) towards prescribing behaviors, in some cases almost suggesting to readers of the Revue Desjardins that they should become Alphonse in the spirit, as is explicit in the quotation above.

Reverence for the founder's exact words is further illustrated in the following example:

It is not necessary to look far to understand Mr. Desjardins' true intentions in founding the Caisses populaires. The second article of the statutes that he himself wrote is so clear and precise that there is no need for further explanation. Let us therefore reread this article once more: it is all of the spirit of the founders that is revealed here and that we must adopt to be in the tradition and doctrine of the founder of the Caisses, Joseph Turmel. Revue Desjardins 20(10), 1954, p.152.

The authoritarian tone of these early imperative invocations may seem surprising to a contemporary reader. The relative fragility of the Caisses populaires in the early years, some of which were not run by full-time professional managers (Poulin, 1994, 1998), may explain why the Federation's managers led by Cyrille Vaillancourt found it necessary to preach unquestioning fidelity to the founder's instructions in enacting the Cooperative doctrine. The important role of the Catholic clergy in the early development of the Caisses populaires may offer a further explanation for the moralizing tone that disappeared completely in the Modern Era.

These imperative invocations show in part how the Cooperative identity (as a doctrine) was continually reinforced during the Foundational Era through the organizational identity work 
of the Federation's managers, and how they achieved this by relying on the founder's words as an infallible source of truth. It does not, however, provide insight into how initial core identity elements could be developed or extended to meet new managerial aspirations. The next category of invocations suggests one way this may happen.

\section{Justificatory invocation: Stretching and sustaining the Cooperative identity}

The [newly created] Société d'investissement Desjardins opens up to the prime objective sought by the founder who insisted on the efficient and concerted organization of credit for productive ends. Quotation from a television interview with Paul-Émile Charron, Director-General of the Federation, Revue Desjardins, 38(1), 1972, p. 55.

Justificatory invocations, the second most frequent type, are particularly focused on legitimating top management decisions and actions based on the founder's ideas. Like existential invocations, they are continuously present over time, though more prevalent during the Foundational Era (66\% of justificatory invocations) than in the Modern Era in parallel with overall intensity of invocations over time. Also like existential and imperative invocations, in the Foundational Era especially, justificatory invocations often rely on extensive citations of the founder's exact words, sometimes reciting his "doctrine” to explain ongoing policies, but more interestingly drawing on his extensive writings to explain how recent managerial initiatives are in fact in conformity with the founder's thinking.

We showed above that the central, distinctive and enduring identity label for Desjardins is that of Cooperation. Moreover, at the "core" of this identity is the Caisse populaire whose key elements designed by Alphonse Desjardins are expressed in Table 5. However, over its history, Desjardins developed far beyond this core into an integrated organization offering a wide range of financial services. Perhaps surprisingly, not only is Alphonse called upon as an authority on the Caisses populaires, but also as a visionary who foresaw later developments, enabling 
managers to legitimate these far beyond his lifetime, thus stretching the Cooperative identity to encompass a wide range of other activities (Table 3).

It seems likely that justificatory invocations were particularly prevalent in the Foundational Era for one major reason: the limits of central control in a Cooperative where the individual caisses maintained considerable autonomy. As historians note (Poulin, 1994; Rousseau \& Levasseur, 1995), the legitimacy of the Federation itself, set up to coordinate the caisses was initially fragile and its relations with the Regional Unions and larger caisses was fraught with tension. In this context, the founder's writings possessed authoritative potential that the Federation's managers could draw on to justify their actions. Indeed, starting with Volume 1 of the Revue Desjardins, we see the founder called on repeatedly to legitimate the very existence of the Federation, and the role of its managers. For example, the first issue cites a letter from the founder's wife supporting the creation of a Federation. Then in 1949, additional "proofs" of Alphonse's intentions are offered in the form of a letter from the founder himself to the caisses written in July 1920 a few months before he died:

Dear Collaborator,

There are currently in the Province of Quebec 160 well-functioning Caisses Populaires. These caisses still have no links between them and have complete managerial autonomy with respect to each other.

This constitutes the realization of a dream that I conceived of when I began this movement of economic organization based around the parish unit which is so perfectly vital in our country. But I also dreamed, to better strengthen these organizations and provide them with a uniform direction corresponding to the ideals that I set myself, to organize a federation where all the caisses would be represented, giving them a new force that would certainly come from having a central organization. (...)

Yours sincerely.

ALPHONSE DESJARDINS

Revue Desjardins 15(3), 1949, p.44.

The Federation Alphonse foresaw was not implemented until 1932, 12 years after his death. However, the traces of this dream reported in the Revue Desjardins (reiterated no less than 45 separate times) offered fodder to others to legitimize the transformation of a loosely 
connected network of autonomous caisses into the coordinated organization it became, contributing to the early construction of a more integrated organizational identity centered around the Federation, and later labeled collectively, the "Mouvement Desjardins.” Here then is a first taste of how justificatory invocations serve to stretch the "core" of Desjardins identity.

In another example, the unfulfilled speculations of Alphonse Desjardins about insurance became the legitimating story that would assist Federation managers in developing this area too, stretching de facto the organization's identity claims again, without betraying the founder's intentions. For example, when an initial foray into insurance occurred in 1944, we read:

The greatest gift that the Caisses populaires could offer to their founder, the Commander Alphonse Desjardins was to create an insurance company, because this eminently clairvoyant individual had seen in insurance the most effective means to deal with the loan-sharkers of the time who were pressuring the people. Revue Desjardins, 11(4), 1945, p.64.

Over 30 quotations in the Foundational Era refer to the insurance arm of Desjardins, incorporating it smoothly into the broader identity of Desjardins beyond the parish-based caisses.

Finally, at the beginning of the Modern Era, as the Desjardins Movement grew, its accumulated resources enabled it to invest in other businesses too. In 1972, it created the Société d'investissement Desjardins (SID) to enable these investments (see the opening quotation of this section). It appears that Alphonse had foreseen this too as part of his ambition that the caisses would lead to the economic emancipation of his people (box 4 of Table 5).

However, the ability to stretch identity in this way was by then reaching its limits. Alphonse Desjardins’ writings could not predict the technological and competitive challenges affecting the financial services sector in the Modern Era. At this point, mobilizing Alphonse's words to stretch organizational identity was less feasible. Thus, as the Modern Era advanced, we see justificatory invocations playing a lesser role, echoing past themes to create symbolic 
precedents, sustaining identity elements but not altering them. For example, Alphonse is cited by a manager of a caisse who offers a musical show to members to get them to attend the general assembly, "Alphonse Desjardins did the same thing in the 1910s, when he invited the bugle corps to the general assembly in Lévis." (Revue Desjardins, 71(4), 2005, p. 21). In another example, Alphonse is cited in support of programs for youth that are said to reflect his perspectives on the importance of education (e.g., compare quotes in Table 1 and Table 5, box 3). Justificatory invocations continue, but they do not have the same power to stretch the Cooperative identity in the Modern Era. This brings us to the last two types of invocation particularly associated with change.

\section{Conservative Invocations: Preserving Cooperative Identity under threat}

As for us, how have we applied the principles set by our founder? Certain neophytes of cooperation sometimes imagine that these principles are not worth anything and that science can change. Some theories of physics, that were previously unknown might change the information that we had previously, I admit that. But I do not believe that God's ten commandments given to Moses several thousands of years ago can change in the year 1954. Cyrille Vaillancourt, Revue Desjardins, 20(10), 1954, p.144.

Both conservative and progressive invocations constitute responses to pressures for

change. In our data, conservative invocations are particularly associated with the Foundational Era (see Table 3). They mobilize the founder in order to limit change and preserve the Cooperative identity, seen here as a doctrine under threat.

For example, one particular feature of the original Cooperative doctrine illustrated in Box 2 of Table 5 is the attachment of the caisses to the local community setting, specifically within parish boundaries. As the number of caisses increased and as some became more successful than others, they began to intrude on each other's territories particularly in the urban centers. In addition, in the 1950s, the officers and managers of the larger so-called "millionaire" caisses banded together to hold conferences and began to pressure the Federation to liberalize restrictive 
credit arrangements (Poulin, 1998). The managers of the Federation, and in particular Cyrille Vaillancourt, its key spokesperson throughout the Foundational Era regularly expressed their concerns in the Revue Desjardins that expansion beyond the parish and alterations to credit rules would destroy the Cooperative identity. Repeatedly, he and others drew on the words or ideas of Alphonse Desjardins to warn against such change as in the following example in which Cyrille Vaillancourt comments on the 1953 conference of the "millionaire" caisses:

Yes, let us beware of being led in a false direction and of losing the spirit that the founder wanted to give to the Caisses. The Caisses populaires must be parish-based organizations, as Mr. Desjardins never ceased to say. Everywhere, he repeated this teaching which is our force and our salvation. Revue Desjardins, 19(6/7), 1953, p. 104.

The same article goes on to cite Alphonse's teachings about the value of restricting the caisse to the parish, and warns of the evils of becoming like banks: "Let us be very careful in urban and semi-urban caisses! Those who are tempted to act like banks.” Vaillancourt goes on, "Our caisses populaires were created by Mr. Desjardins to help the little people. We have no right to take their savings to help in the construction of large buildings, to engage in speculation, aiming only to make money."

The identity work carried out here seems aimed at containing the ambitions of officers and managers of the larger caisses in order to preserve the founder's vision of the Cooperative identity that risks seeping away just as the centrality of the parish community to Quebec society is fading in importance. The foundational Cooperative doctrine and Alphonse's heritage is constructed here as immutable, the only legitimate basis for continuation, expressed again strikingly in the opening quotation of this section using a biblical analogy. How then did Desjardins escape from this impasse? 


\section{Progressive invocations: Refreshing Cooperative identity while enabling continuity}

"At the time of the founder," noted the President, "the parish was the basic community of interest. Today, we have to think differently to try to define the basic community of interest of the caisse." Revue Desjardins, 72(2), 2006, p. 15. Report on speech by Alban D’Amours, President of Desjardins.

While justificatory invocations allow change by stretching conceptions of the Cooperative identity, drawing on Alphonse's writings to legitimate expansion and diversification, progressive invocations work differently to allow change by refreshing identity elements. Unlike conservative and imperative invocations that seem to deny any derogation from Alphonse's exact words, progressive invocations explicitly recognize that change is inevitable, but do so while maintaining the founder as a key identity marker. What is referenced however is not Alphonse's explicit writings or instructions, but aspects of the founder that are one or two degrees removed from these: typically, either (a) a broader philosophical interpretation of his ideas, or (b) aspects of Alphonse’s persona or heritage that situate him as a role model.

The first of these is illustrated in articles concerning the disappearance of the parish as a basis for defining the community supporting the caisses.

The genius of Alphonse Desjardins was to attach the Caisse populaire to the life force of the parish of his time, already structured and organized. This base has changed and will continue to change. We must reattach the caisses to today's base: the community in the caisse and the caisse in the community. Fidelity to the past, yes, but above all, fidelity to the future. Revue Desjardins, 69(2), 2003, p. 17.

More interesting perhaps is the second form of progressive invocation that shift discussions of Alphonse's heritage to a different plane, not by attempting to rethink his concepts, but by drawing on him as a role model as illustrated in the following quotation from the first article penned by President Alfred Rouleau in 1972 just after his election:

It has been said of Alphonse Desjardins that he knew exactly what to keep, what to change, and as needed, what to innovate. It has also been said of him that he knew how to remind his collaborators of the social duty of adaptation as well as of the democratic demands of cooperation. 
The democratic demands of cooperation are still very real.

The social duty of adaptation is the preoccupation of hundreds and of thousands of directors among the 17,000 volunteer officers of our caisses populaires and our institutions. (...) Adaptation... is the sign of life itself.

The notion of adaptation is inscribed in a perspective that involves a harmonious reconciliation between the rich lessons of Desjardins' past whose value is perhaps unique in the world, and a rational projection of the needs and aspirations of the generations of tomorrow.

This is why, for my part, and since yesterday in particular, I cannot get out of my mind the primary concerns that have always been attributed to Alphonse Desjardins: What to keep? What to change? What to innovate? (Alfred Rouleau, newly elected President, Revue Desjardins, 38(3), 1972, p.5-7.

The contrast between this excerpt and those in the previous section on conservative invocation is stark. While it is clear that the cooperative identity is still viewed as central and enduring (e.g., references to "democratic demands" and "the rich lessons of Desjardins' past), there is now explicit attention to innovation and adaptation, themes that were previously treated negatively. Moreover, no longer are Alphonse's teachings cited as literal templates for action. Rather, it is his persona as a visionary and change agent that is referenced. Alfred Rouleau's presidency essentially ushered in the Modern Era. From then on, we see multiple examples of progressive invocation that rise above the constraints of the prior Foundational Era, refreshing Desjardins' Cooperative identity, though injecting it with a greater dose of ambiguity. Note however, how the continued citation of Alphonse, now liberated from the bonds of doctrinal interpretations nevertheless allows continuity during change.

\section{Overarching trends: From literal to allusive founder invocations}

Across the analysis of the five types of invocation, one overarching trend emerges strikingly in comparing data from the Foundational and the Modern Era. This is the degree to which the founder is referred to in a literal or an allusive way. In the Foundational era, invocations of all types often use the founder's exact words, and the meaning implied is literal. Later however, the founder's words take on a more symbolic or metaphorical meaning. As the 
Cooperative identity shifts from a doctrine to a distinction, expressions used by the founder are taken out of context and become slogans. See for example, the 1989 quotation for existential invocation in Table 1 where the notion of "union for life" from Alphonse Desjardins is used to refer to the strength of cooperative association, without specifying its exact content.

In addition to the patterns associated with specific types of invocation noted above, an additional form of change in invocations across eras is what we might call "selective forgetting," in which dimensions that initially seemed important to the founder's connection with organizational identity are simply dropped. A specific example is the link to religious elements. For example, the expression "union for life" is frequently cited in the Revue Desjardins but this comes from a longer text by Alphonse in which he describes the Caisse populaire as, "The expression of a truly Christian and elevated social duty in the economic domain." The religious connection is often present when the expression is cited in the Foundational era, but disappears by the 1970s, as do other religious references, coinciding with the transformations of the "Quiet Revolution” during which the Catholic domination of Quebec institutions was suppressed.

Overall, in the Modern Era, the founder is often invoked to allude to the Cooperative identity without lengthy elaboration. A final example of how invocations express Desjardins' Cooperative identity in increasingly abstract and allusive ways is provided in Figure 2. This cover image from Revue Desjardins in 2008 shows in visual form the centrality of the founder to organizational identity, while leaving readers to imagine its meaning. Monique Leroux, the newly elected President appears surrounded by the officers who elected her under a giant portrait of Alphonse Desjardins symbolically pointing the way. The caption "En route vers 2012" (Towards 2012) expresses direction towards the future in continuity with the past, while the large 
group of officers surrounding her signals their collective commitment to this direction as well as solidarity with the founder and the new leader they have elected.

Insert Figure 2 here

\section{Discussion and Conclusion}

In this paper, we asked, "How is the founder figure invoked in organizational communications to construct organizational identity through changing times?” Our findings traced patterns of founder invocation and organizational identity work for a single organization over 80 years, providing a rare longitudinal perspective on the uses of the founder figure in organizational communications. Table 3 summarized the findings of our study showing how different forms of invocation participate in organizational identity work, and how they evolve from literal to allusive references to the founder. While organizations have unique histories, the patterns described and their progressive abstraction have some potentially generic qualities. We now discuss the key conceptual insights emerging from the study.

\section{Founder invocation as organizational identity work}

A first insight concerns the ways in which the different types of invocations do organizational identity work, i.e., influence audience understandings of the central, distinctive and enduring characteristics of the organization, and by so doing draw audience members into that identity. For example, we saw that existential invocations glorify the Cooperative identity associated with the founder, whether as a doctrine or as a distinction, assigning positive value to it using terms such as "rich in ideals," and associating it with "prosperity, welfare and security for all," or even "the salvation of society." Existential invocations thus clearly contribute to "remembering,” as Suddaby et al. (2016) call it, encouraging identification with the organization and with its founder. "Re-membering" is a term that seems particularly apt here given that the 
audiences are indeed "members" in a literal sense. Their "member-ship" is also essential to maintaining the vitality of the Cooperative identity because of their specific role in the organization’s democratic governance (see Table 5).

The image shown in Figure 2 illustrates perfectly the powerful role of founder invocation in organizational identity work. The image pulls members in by symbolically showing their representatives, their President and Alphonse grouped together in Cooperative solidarity. The Revue Desjardins is clearly an ongoing site for organizational identity work, and the founder Alphonse Desjardins is a central symbol in that work.

\section{Founder invocation as ventriloquism}

While existential invocations articulate central, distinctive and enduring elements of organizational identity, and enable members to partake in it as members, the other forms of invocation are oriented towards action and draw on these central, distinctive and enduring elements for other ends. Organizational identity is still central. However, with their emphasis on action, these invocations place the audience in somewhat different roles, and situate the founder in different relations to that audience. One significant observation from our study is the degree to which the founder is drawn on as a key source of truth and authority concerning identity, its enactment, its development and its preservation especially in the Foundational Era.

For example, imperative invocations treat the audience as recipients of orders from the founder. They exhort readers to action in order to enact the Cooperative identity. The audience is treated here as an executor of Alphonse's wishes. By contrast, justificatory invocations attempt to legitimize actions by top management that stretch or sustain organizational identity. Here the audience is treated as a judge of top management actions, and it is managers themselves who adopt the role of executors of Alphonse's wishes. Note however that in both cases, authority is 
constructed as coming not from managers directly, but from the founder himself to whom others are constructed as subordinate. Similarly, conservative invocations are aimed at preserving organizational identity elements. The audience to whom these invocations seem directed are recalcitrant officers and managers who might be tempted to depart from the founder's Cooperative doctrine. Again, authority is invested in the founder. Only progressive invocations seem to fully share agency with the founder, distancing him more from the action, though retaining him as an observer or role model. Overall, the Foundational Era is dominated by a form of invocation in which ultimate authority is discursively assigned to the founder, a pattern that continues remarkably, for nearly 50 years after the founder's death.

Following Cooren (2010, p. 1), we refer to this phenomenon using the metaphor of ventriloquism, defined as the way in which "an actor makes another actor speak through the production of a given utterance." The founder is in some sense treated as the ventriloquist's "dummy" made to speak by managers to make their own messages more authoritative, legitimate and palatable to audiences.

Founder ventriloquism may however also have negative side-effects for the managers that apply it extensively. By crediting the founder with so much authority and foresight, managers may efface to some degree the traces of their own nevertheless significant contributions from organizational memory. Indeed, although Cyrille Vaillancourt was called the "Second Founder of the Caisses Populaires" during his lifetime, Maheu (2013) notes that he is "often forgotten" even though he was largely responsible for the growth and transformation of Desjardins into a large financial services enterprise as well as for the preservation of its Cooperative identity. 


\section{Founder invocation as increasingly abstract and allusive over time}

The study also revealed how founder invocations are likely to become increasingly abstract and allusive over time in parallel with shifts in the meanings underlying the central, distinctive and enduring identity labels associated with the founder. We argue that paradoxically, this is may be the only way that a founder's name can be retained as an important identity marker given the inevitability of significant contextual change demanding departure from narrow conceptualizations developed at founding. As we suggested, progressive invocations that refresh the founder's linkage with organizational identity, and selective forgetting that strips away dated associations are two mechanisms by which this increasing abstraction occurs.

Previous studies offer other examples that suggest similar processes of abstraction from literal to more abstract and allusive invocations, without drawing attention to this phenomenon directly. For example, in their study of Carlsberg, Hatch and Schultz (2017) showed how the slogan "Semper Ardens" attributed to the founder's son twice became a powerful identity symbol with perceived authenticity. And yet, this slogan - clearly symbolic - does not reveal much at all about the founding identity. It is detached from its origins and reinterpreted. Hatch and Schultz (2017) also note in passing that Semper Ardens replaced the founder's "Golden Words” inscribed in his will as a key identity reference, a striking parallel with our own observations of the shift between emphasis on a Cooperative "doctrine" based on the founder's words to a more abstract Cooperative "distinction" associated in a looser way to the founder's heritage and persona. Anteby and Molnàr's (2012) study of identity work at an aviation company also draws attention to processes of forgetting. Note however, that in contrast to Anteby and Molnár's (2012) study, forgetting in our case is progressive, implying gradual disappearance over time of certain referents rather than their complete neglect. 


\section{Explaining founder longevity as a resource for organizational identity work}

The case studied here is in many ways exceptional. Although some organizations use founder figures in their communications long after their demise, many do not. This leads us to ask which elements might help explain the presence and longevity of founders as resources for rhetorical history and organizational identity work.

A first element that could help explain why deceased founders may become valued resources in the first place is related to perceived weaknesses in managerial legitimacy or authority. As in the case of Desjardins, fragile legitimacy may stimulate reliance on founder invocation to justify actions and claims that might otherwise be questionable. In Desjardins' case, weakness was related to limitations in authority based on the origins of the Federative structure. However, one might imagine similar situations occurring, for example, when an inexperienced family member unexpectedly takes the reins of a family firm.

A second factor that may contribute to longevity is related to the founder him or herself, and in particular the apparent temporal depth of their written or material heritage. Alphonse Desjardins' writings could be constructed as having remarkable temporal depth that extended far beyond the Caisse populaire itself as it was when he died. Thus, fifty years after his death, Desjardins' managers were able to draw on his words to stretch organizational identity, suggesting that the founder had already foreseen what they were contemplating. The presence of such tangible traces clearly contributes to his longevity.

Third, the long tenure of early successors who engage in founder ventriloquism is likely to extend the longevity of founder figures as rhetorical resources. At Desjardins, Cyrille Vaillancourt's 35-year record of drawing on Alphonse to legitimate his decisions no doubt contributed to the founder's continued centrality. To the extent that newsletters like the Revue 
Desjardins are mnemonics (Rowlinson, Booth, Clark, Delahaye, \& Procter, 2010), i.e., repositories of organizational memory, there may be a path-dependent pattern occurring, where past uses of history laid down in text set bounds on future uses. After 35 years, it would not be a simple matter for Cyrille Vaillancourt's successors to detach themselves completely from the founder, even had they wished to, given his evident importance to everything Desjardins stood for as inscribed in the Revue Desjardins, and in other artefacts valued by members.

Finally, in value-driven organizations like cooperatives that have grown to become major corporations, it is possible that the image of the founder may remain central as an identity symbol in part because of the weakening hold of these values in operating practices. In other words, Desjardins like other similar organizations (e.g., the dairy cooperative studied by Mordhorst, 2014) conserves its values as part of its raison d'être, while the organization itself has become increasingly similar to its competitors in terms of client relations (like a bank). In such situations, the distinctive nature of the organization is at stake, raising questions of legitimacy and strategic advantage. It may be important to recall founders as symbols of continuity, more especially when the organization has dramatically changed through time.

\section{Directions for future research}

Our study revealed five ways by which a founder figure might be invoked over extended periods of time. Many opportunities for further research remain however. First, the current study focused specifically on organizational identity work by managers. Yet, founder figures may be contested resources, with different stakeholders "using” their memory in different ways. For example, the history of Carly Fiorina's tenure at Hewlett-Packard offers an example of how different interpretations of the heritage of the firm's founders Bill Hewlitt and David Packard led to organizational conflict and Fiorina’s eventual departure (Elsbach, Stigliani, \& Stroud, 2012). 
There is clearly room for further research on the potentially contested nature of founder figures, and how this might play into organizational identity work beyond the managerial level.

Relatedly, the questions of who may legitimately speak for a deceased founder, and what limits may exist on the way their memory is invoked are also topics for study. Our research seems to suggest that long after the founder's death, there may be considerable flexibility in the content of invocations. And yet, to the extent that audiences have succumbed to prior rhetorical strategies of re-membering (Suddaby et al., 2016), they could become "identity custodians" (Howard-Grenville, Metzger, \& Meyer, 2013) who might then resist what they see as the betrayal of founding values and prior interpretations of them.

Finally, another topic for study concerns the degree of reflexivity lying behind the use of founder figures in organizational identity work. The rhetorical history perspective treats uses of history as "strategic" (Suddaby et al., 2010). We saw the strategic nature of founder invocations through the way in which Alphonse is discursively mobilized to promote certain ideas and not others. Yet, we did not have access to the deliberations, if any, that lay behind the texts we analyzed, nor to the writers themselves. With such access, future studies might unpack in more depth the degree to which uses of history are conscious, deliberate and manipulative, or rather more the manifestations of managers' commitment to founding values and their search for authenticity (see Hatch \& Schultz, 2017). It is an open question whether rhetorical uses of history may sometimes seduce their producers as much, if not more, than their audiences.

\section{References}

Albert, S., \& Whetten, D. A. (1985). Organizational Identity. In L. L. Cummings \& M. M. Staw (Eds.), Research in Organizational Behavior (Vol. 7, pp. 263-275). Greenwich, CT: JAI Press.

Anteby, M., \& Molnár, V. (2012). Collective Memory Meets Organizational Identity: Remembering to Forget in a Firm's Rhetorical History. Academy of Management Journal, 55(3), 515-540. 
Balakrishnan, A. (2016). Why Apple CEO Tim Cook doesn't ask, 'What would Steve Jobs do?' downloaded from http://www.cnbc.com/2016/10/03/why-apple-ceo-tim-cook-doesnt-askwhat-would-steve-jobs-do.html, April 24, 2017.

Blombäck, A., \& Brunninge, O. (2013). The dual opening to brand heritage in family businesses. Corporate Communications: An International Journal, 18(3), 327-346.

Brunninge, O. (2009). Using history in organizations: How managers make purposeful reference to history in strategy processes. Journal of organizational change management, 22(1), 826.

Chreim, S. (2002). Influencing Organizational Identification During Major Change: A Communication-Based Perspective. Human Relations, 55(9), 1117-1137.

Chreim, S. (2005). The Continuity-Change Duality in Narrative Texts of Organizational Identity. Journal of Management Studies, 42(3), 567-593.

Cooren, F. (2010). Action and Agency in Dialogue: Passion, Incarnation and Ventriloquism. Amsterdam, Netherlands: John Benjamins Publishing.

Elsbach, K. D., Stigliani, I., \& Stroud, A. (2012). The building of employee distrust: A case study of Hewlett-Packard from 1995 to 2010. Organizational Dynamics, 41(3), 254-263.

Foster, W. M., Suddaby, R., Minkus, A., \& Wiebe, E. (2011). History as social memory assets: The example of Tim Hortons. Management \& Organizational History, 6(1), 101-120.

Gioia, D. A., Corley, K. G., \& Fabbri, T. (2002). Revising the past (while thinking in the future perfect tense). Journal of organizational change management, 15(6), 622-634.

Gioia, D. A., Patvardhan, S. D., Hamilton, A. L., \& Corley, K. G. (2013). Organizational Identity Formation and Change. Academy of Management Annals, 7(1), 123-193.

Gioia, D. A., Schultz, M., \& Corley, K. G. (2000). Organizational Identity, Image, and Adaptive Instability. Academy of Management Review, 25(1), 63-81.

Hatch, M. J., \& Schultz, M. (2017). Toward a Theory of Using History Authentically: Historicizing in the Carlsberg Group. Administrative Science Quarterly, 62(4), 657-697.

Howard-Grenville, J., Metzger, M. L., \& Meyer, A. D. (2013). Rekindling the Flame: Processes of Identity Resurrection. Academy of Management Journal, 56(1), 113-136.

Jaskiewicz, P., Combs, J. G., \& Rau, S. B. (2015). Entrepreneurial legacy: Toward a theory of how some family firms nurture transgenerational entrepreneurship. Journal of Business Venturing, 30(1), 29-49.

Kreiner, G. E., \& Murphy, C. (2016). Organizational Identity Work. In M. Pratt, M. Schultz, B. E. Ashforth, \& D. Ravasi (Eds.), The Oxford Handbook of Organizational Identity (pp. 276-293). Oxford, UK: Oxford University Press.

Lévesque, B. (Ed.) (1997). Desjardins: Une Entreprise et un Mouvement? Québec: Presses de l'Université du Québec.

Maclean, M., Harvey, C., Sillince, J. A., \& Golant, B. D. (2014). Living up to the past? Ideological sensemaking in organizational transition. Organization, 21(4), 543-567.

Mordhorst, M. (2008). From counterfactual history to counter-narrative history. Management \& Organizational History, 3(1), 5-26.

Mordhorst, M. (2014). Arla and Danish national identity-business history as cultural history. Business History, 56(1), 116-133.

Nissley, N., \& Casey, A. (2002). The politics of the exhibition: Viewing corporate museums through the paradigmatic lens of organizational memory. British Journal of Management, 13(S2), S35-S45. 
Pinch, T. J., \& Bijker, W. E. (1984). The social construction of facts and artefacts: Or how the sociology of science and the sociology of technology might benefit each other. Social studies of science, 14(3), 399-441.

Poulin, P. (1994). Histoire du Mouvement Desjardins. Tome II: La pecée des caisses populaires 1920-1944. Montréal: Québec-Amérique.

Poulin, P. (1998). Histoire du Mouvement Desjardins. Tome III: De la caisse locale au complexe financier 1945-1971. Montréal: Québec-Amérique.

Poulin, P., \& Tremblay, B. (2005). Desjardins en mouvement. Montréal: Presses HEC Montréal, Les Éditions Dorimène.

Rousseau, Y., \& Levasseur, R. (1995). Du comptoir au réseau financier: l'expérience historique du Mouvement Desjardins dans la région du centre du Québec, 1909-1970: [Montréal]: Boréal.

Rowlinson, M. (2002). Cadbury World. Labour History Review, 67(1), 101-119.

Rowlinson, M., Booth, C., Clark, P., Delahaye, A., \& Procter, S. (2010). Social remembering and organizational memory. Organization Studies, 31(1), 69-87.

Rowlinson, M., \& Hassard, J. (1993). The invention of corporate culture: A history of the histories of Cadbury. Human Relations, 46(3), 299-326.

Schultz, M., \& Hernes, T. (2013). A temporal perspective on organizational identity. Organization Science, 24(1), 1-21.

Suddaby, R., Foster, W. M., \& Quinn Trank, C. (2010). Rhetorical history as a source of competitive advantage. In J. A. C. Baum \& J. Lampel (Eds.), The Globalization of Strategy Research (Advances in Strategic Management, Volume 27) (pp. 147-173): Emerald Group Publishing Limited.

Suddaby, R., Foster, W. M., \& Quinn Trank, C. (2016). Re-membering: Rhetorical history as identity work. In M. G. Pratt, M. Schultz, B. E. Ashforth, \& D. Ravasi (Eds.), The Oxford Handbook of Organizational Identity (pp. 297-316). New York: Oxford University Press.

Sveningsson, S., \& Alvesson, M. (2003). Managing Managerial Identities: Organizational Fragmentation, Discourse and Identity Struggle. Human Relations, 56(10), 1163-1193.

Watson, T. J. (2016). Organizational Identity and Organizational Identity Work as Valuable Analytical Resources. In M. Pratt, M. Schultz, B. E. Ashforth, \& D. Ravasi (Eds.), The Oxford Handbook of Organizational Identity (pp. 123-139). Oxford, UK: Oxford University Press.

Zundel, M., Holt, R., \& Popp, A. (2016). Using history in the creation of organizational identity. Management \& Organizational History,, 11(2), 211-235. 


\section{Table 1: Quotations Illustrating Five Types of Founder Invocation}

\begin{tabular}{|c|}
\hline Codes and illustrative coded extracts \\
\hline $\begin{array}{l}\text { Existential invocation: Relating the founder directly to organizational mission and values (561 quotations) } \\
\text { The vast project led by the Movement cannot be summed up in a few lines, but some important elements can be } \\
\text { identified. This project consists of constructing together a strong economy that will bring prosperity, welfare and } \\
\text { security for all. The project also involves bringing together private interests and the common good through solidarity } \\
\text { and democratic action. It consists of reinforcing the actions of all through the strength of association, and through } \\
\text { the strength of “union for life” in Alphonse Desjardins' words. Revue Desjardins, 55(6), 1989, p.23. }\end{array}$ \\
\hline $\begin{array}{l}\text { Imperative invocation: Commanding action in the name of the founder (211 quotations) } \\
\text { Work to develop savings practices in your own parish by founding school cooperatives, study circles, etc. (...) In a } \\
\text { nutshell, make your Caisse Populaire into an institution whose social role will be faithful to our founder’s ideas. } \\
\text { Only then will you have deserved respect from your fellow citizens. Revue Desjardins, 11(10), 1945, p.187. }\end{array}$ \\
\hline $\begin{array}{l}\text { Justificatory invocation: Justifying ongoing actions based on the founder's ideas (503 quotations) } \\
\text { More than one hundred years later, Alphonse Desjardins' objectives are more relevant than ever, as we can see with } \\
\text { our new business positioning for youth. The Revue Desjardins presents here some of the key actions that will be } \\
\text { deployed gradually during the next three years. Revue Desjardins, 78(3), 2012, p.12. }\end{array}$ \\
\hline $\begin{array}{l}\text { Conservative invocation: Resisting change based on the founder's ideas (45 quotations) } \\
\text { Our founder imagined a simple accounting system. Let us keep it simple, while improving it by changing the details } \\
\text { if needed, but let us never give way to the whims of useless innovations, that can sometimes be ridiculous. Beware } \\
\text { of this mania for change that drives some innovators, who are not sufficiently imbued with the cooperative } \\
\text { principles on which our Caisses Desjardins are built. Revue Desjardins, 12(4), 1946, p.71. }\end{array}$ \\
\hline $\begin{array}{l}\text { Progressive invocation; Promoting change while maintaining link to the founder (79 quotations) } \\
\text { I would like to conclude by sharing my strongly held conviction about the future of the Mouvement Desjardins. We } \\
\text { are at a crucial moment in our history. We are going through a financial crisis, just like } 110 \text { years ago when } \\
\text { Alphonse Desjardins created his model of the Caisse. We have here a window of opportunity to renew and reaffirm } \\
\text { the pertinence of who we are. Revue Desjardins, } 77(4), 2011, \text { p.31. }\end{array}$ \\
\hline
\end{tabular}




\section{Table 2: Epochs in the History of Desjardins: Key Leaders and Events}

\begin{tabular}{|c|c|}
\hline \multicolumn{2}{|r|}{ 1900: FOUNDATION OF THE FIRST CAISSE POPULAIRE } \\
\hline \multirow{2}{*}{ 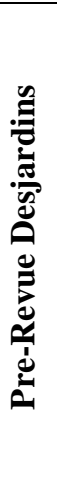 } & $\begin{array}{l}\text { 1900-1920: Foundation and Early Development of the Caisses } \\
\text { - Key leaders: Alphonse Desjardins, his wife Dorimène, clergy, collaborators, activists } \\
\text { 1900: Foundation of the first Caisse Populaire in Lévis, Québec } \\
\text { 1906: Legislative framework for cooperatives adopted by the Quebec National Assembly } \\
\text { 1900-1920: Foundation of } 136 \text { Caisses populaires in Quebec, } 19 \text { in Ontario and } 9 \text { in the U.S. } \\
\text { 1920: Death of Alphonse Desjardins }\end{array}$ \\
\hline & $\begin{array}{l}\text { 1920-1935: Foundation of Coordinating Structures } \\
\text { - Key leaders: Cyrille Vaillancourt, first President of the Federation and others in regions } \\
\text { 1920: Foundation of Trois-Rivières Regional Union, followed by } 3 \text { others (Quebec City, Montreal, Gaspé) } \\
\text { 1932: Foundation of the Federation for inspections and coordination of caisses and Regional Unions } \\
\text { 1920-1935: Growth in number of Caisses populaires to } 239 \text { in } 1935 \\
\text { 1935: Creation of the magazine Caisse Populaire Desjardins, a forerunner of the Revue Desjardins }\end{array}$ \\
\hline \multicolumn{2}{|r|}{ 1935: FOUNDATION OF THE REVUE DESJARDINS } \\
\hline & $\begin{array}{l}\text { 1935-1969: Growth and Development of Caisses Network and Financial Services Subsidiaries } \\
\text { - Key leaders: Cyrille Vaillaincourt, President (1932-1936) and later General Manager of the } \\
\text { Federation; Key spokesperson until his death in 1969. Other individuals served as Presidents during the } \\
\text { same time including Émile Girardin 1959-1972. } \\
\text { 1935-1969: Growth of number of Caisses populaires from } 239 \text { in } 1935 \text { to } 1097 \text { in } 1950 \text { and to } 1330 \text { in } 1970 \\
\text { 1944: Foundation of a General Insurance Company } \\
\text { 1948: Foundation of Life Insurance Company } \\
\text { 1960-1970: Acquisitions in various branches of financial services including trust and investment banking } \\
\text { 1963: Major convention leading to greater acceptance of consumer credit } \\
\text { 1969: Death of Cyrille Vaillancourt }\end{array}$ \\
\hline \multirow{4}{*}{ 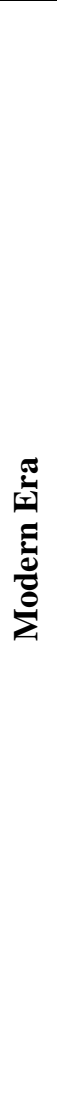 } & $\begin{array}{l}\text { 1970-1981: Modernization and Investment in Quebec Business } \\
\text { - Key leaders: (1) Émile Girardin, President 1959-1972. (2) Alfred Rouleau, President and Chief } \\
\text { Executive, 1972-1981, formerly President of the life insurance arm of Desjardins (since 1948). } \\
\text { 1970: Acquisition of 83\% of food company Vachon (later Culinar) } \\
\text { 1974: Creation of the Société d'investissements Desjardins (SID) to invest in Quebec business enterprise } \\
\text { 1970-1981: Implementation of computer systems enabling member transactions across caisses } \\
\text { 1979: Foundation of the Société Historique Desjardins } \\
\text { 1970-1981: Stability in number of caisses; Members increase from } 2.5 \text { million to } 3.35 \text { million in } 1980\end{array}$ \\
\hline & $\begin{array}{l}\text { 1981-1987: Development of Services and Consolidation } \\
\text { - Key leader: Raymond Blais, President and Chief Executive, } 1981-1986 \\
\text { 1981: Introduction of a credit card (after years of hesitation) and automatic teller machines (ATMs) } \\
\text { 1984-1986: Exercise to refine the mission and values of Desjardins } \\
\text { 1981-1987: Stability in number of caisses; Members increase to } 4.5 \text { million in } 1990\end{array}$ \\
\hline & $\begin{array}{l}\text { 1987-1999: Reengineering and Restructuring } \\
\text { • Key leader: Claude Béland, President and Chief Executive, 1987-1999 } \\
\text { 1994-1999: Major reengineering initiative to reduce costs of operations in the caisse } \\
\text { 1996: Implementation of Accès D internet banking } \\
\text { 1999: Restructuring eliminating middle level of coordination and renewing democratic governance } \\
\text { 1990-1999: Caisses down from } 1329 \text { in } 1990 \text { to } 972 \text { in } 2000 \text { (mergers): Members: } 5 \text { million in } 2000 .\end{array}$ \\
\hline & $\begin{array}{l}\text { 2000-2016: Renewal and Expansion } \\
\text { - Key leaders: (1) Alban d'Amours, President and Chief Executive, 2000-2008; } \\
\text { - (2) Monique Leroux, President and Chief Executive, 2008-2016 (first woman President) } \\
\text { 2000-2003: Implementation of new integrated structure (further renewal in 2008) } \\
2000 \text { and 2015: Acquisitions in insurance : La Personnelle in 2000; State Farm in } 2015 \\
2012 \text { : International Summit of Cooperatives hosted by Desjardins in Lévis } \\
\text { 2000-2016: Over 7,000,000 members in 2015; Number of caisses down to } 335 \text { due to ongoing mergers } \\
\text { 2000-2016: Total assets increase from \$76 billion to \$248 billion with financial services acquisitions }\end{array}$ \\
\hline
\end{tabular}




\section{Table 3: Invocations and Organizational Identity Work across Eras at Desjardins}

\begin{tabular}{|c|c|c|}
\hline $\begin{array}{l}\text { Types of invocation } \\
\text { Relation to organizational identity }\end{array}$ & Foundational Era 1935-1969 & Modern Era 1970-2015 \\
\hline $\begin{array}{l}\text { Existential invocations } \\
\text { - Articulating central, } \\
\text { distinctive and enduring } \\
\text { elements }\end{array}$ & $\begin{array}{l}\text { Defining Cooperative identity as a } \\
\text { "doctrine" grounded in the founder's } \\
\text { writings }\end{array}$ & $\begin{array}{l}\text { Defining Cooperative identity as a } \\
\text { "distinction” associated with the } \\
\text { founder's heritage and persona }\end{array}$ \\
\hline $\begin{array}{l}\text { Imperative invocations } \\
\bullet \quad \text { Enacting central, distinctive } \\
\text { and enduring elements }\end{array}$ & $\begin{array}{l}\text { Commanding conformity to the } \\
\text { "doctrine" in the name of the founder } \\
\text { as expressed in his writings }\end{array}$ & Rare \\
\hline $\begin{array}{l}\text { Justificatory invocations } \\
\bullet \quad \begin{array}{l}\text { Stretching or sustaining } \\
\text { central, distinctive and } \\
\text { enduring elements }\end{array}\end{array}$ & $\begin{array}{l}\text { Stretching Cooperative identity to } \\
\text { encompass developments fore- } \\
\text { shadowed in the founder's writings }\end{array}$ & $\begin{array}{l}\text { Sustaining Cooperative identity by } \\
\text { linking current actions to the founder's } \\
\text { past actions and ideas }\end{array}$ \\
\hline $\begin{array}{l}\text { Conservative invocations } \\
\text { • } \quad \text { Preserving central, distinctive } \\
\text { and enduring elements }\end{array}$ & $\begin{array}{l}\text { Resisting change in Cooperative } \\
\text { identity by affirming the immutable } \\
\text { nature of founder's “doctrine” }\end{array}$ & Rare \\
\hline $\begin{array}{l}\text { Progressive invocations } \\
\text { • } \quad \text { Refreshing central, distinctive } \\
\text { and enduring elements }\end{array}$ & Rare & $\begin{array}{l}\text { Promoting change while enabling } \\
\text { continuity in Cooperative identity by } \\
\text { recasting the founder's ideas }\end{array}$ \\
\hline Trend across all invocations & $\begin{array}{l}\text { Literal interpretation of the founder's } \\
\text { words and ideas }\end{array}$ & $\begin{array}{l}\text { Allusive interpretation of the founder's } \\
\text { heritage and persona }\end{array}$ \\
\hline
\end{tabular}

\section{Table 4: The founder as enduring symbol of Cooperative identity: From 1935-2011}

\begin{tabular}{|c|c|}
\hline $\begin{array}{l}\text { Example from the Foundational Era } \\
\text { Revue Desjardins, 1(1), 1935, p.2 (Opening article in } \\
\text { first issue signed A.R. Laplaine) }\end{array}$ & $\begin{array}{c}\text { Example from the Modern Era } \\
\text { Revue Desjardins, 77(4), 2011, p.31 (Interview with } \\
\text { Monique Leroux, President) }\end{array}$ \\
\hline $\begin{array}{l}\text { WE ARE?... "THE CAISSE POPULAIRE } \\
\text { DESJARDINS" [name of the Revue Desjardins until } \\
\text { 1941]. Nothing more, nothing less. How many times did } \\
\text { the founder of the caisses, the late Commander Alphonse } \\
\text { Desjardins dream about this modest publication? His } \\
\text { dream has at last been realized (...) } \\
\text { The topics to be handled? Cooperation in all its forms, } \\
\text { but especially savings and loan cooperatives: the Caisse } \\
\text { Populaire (...) } \\
\text { Note right way that "THE CAISSE POPULAIRE } \\
\text { DESJARDINS" does not claim infallibility; but do not } \\
\text { fear, it will always be honest. It will simply present as } \\
\text { best it can the cooperative doctrine (...). We call on all } \\
\text { men of good will to propagate the ideas of healthy } \\
\text { cooperation in our dear province. Does not the salvation } \\
\text { of society depend on it? }\end{array}$ & $\begin{array}{l}\text { Revue Desjardins: Cooperation and commitment are } \\
\text { part of the strategic plan. You seem to take these values } \\
\text { particularly to heart! } \\
\text { Monique Leroux: These two dimensions are intrinsic } \\
\text { to our nature. Alphonse Desjardins was a cooperator at } \\
\text { heart, and at the same time, he called on the notion of } \\
\text { self-help and commitment to solidarity. } \\
\text { (...) } \\
\text { The issue is to make our cooperative distinction } \\
\text { tangible, concrete. It is not talk that will achieve this but } \\
\text { actions. In this respect, the Coopme program and its four } \\
\text { major levers propose concrete actions in terms of } \\
\text { personal commitment, education, responsible financial } \\
\text { products and service offerings and the promotion of } \\
\text { cooperation. }\end{array}$ \\
\hline
\end{tabular}




\section{Table 5: Four Core Elements in Existential Invocations 1935-1969}

\begin{tabular}{|c|c|}
\hline $\begin{array}{l}\text { 1. Democratic principles } \\
\text { It is the rule of equality that regulates relations among } \\
\text { members [of a cooperative]. This rule is expressed in the } \\
\text { principle: one man, one vote. In his presentation of the } \\
\text { motivations for the bill on cooperative syndication, Mr. } \\
\text { Alphonse Desjardins wrote, "What characterizes above all a } \\
\text { cooperative and that differentiates it from any other } \\
\text { association founded on a philosophy of pure speculation or } \\
\text { profit, is the perfect equality of members in terms of their } \\
\text { individual right to regulate its workings and to influence its } \\
\text { decisions." Revue Desjardins, 20(11), 1954, p. 179; } \\
\text { Information service }\end{array}$ & $\begin{array}{l}\text { 2. Local community-embeddedness } \\
\text { "The purpose of the Caisse populaire,” wrote the founder in } \\
\text { 1919, "is to complete the organization of the parish. The } \\
\text { parish unit has been incomplete until now because there was } \\
\text { no organization looking after the economic needs of the } \\
\text { population (...). It is this that the Caisse populaire is called } \\
\text { on to correct, by creating a reservoir of savings and credit } \\
\text { placed in the service of all honest people of the parish, } \\
\text { enabling and stimulating the spirit of economy and ensuring } \\
\text { through the accumulated resources the credit needs of } \\
\text { members of the caisse.” Revue Desjardins, 1(1), 1935, p. 7). }\end{array}$ \\
\hline $\begin{array}{l}\text { 3. Educational role } \\
\text { Mr. Desjardins wanted to create an institution where people } \\
\text { would learn to practice economic and social virtues in their } \\
\text { everyday lives. He realized that the best way to improve the } \\
\text { economic and social situation of his countrymen was to help } \\
\text { them help themselves. (..) Thus, the Caisse populaire, } \\
\text { according to the founder's ideas, aims to encourage everyone } \\
\text { to practice economy, which is the art of managing goods with } \\
\text { wisdom, foresight, prudence and reason in order to obtain the } \\
\text { best returns possible. Revue Desjardins, 27(6/7), 1961, p. } \\
\text { 117, Information Service. }\end{array}$ & $\begin{array}{l}\text { 4. Economic emancipation } \\
\text { The Caisses populaires Desjardins have, for fifty years, made } \\
\text { clear by constant education this necessity for credit, but } \\
\text { healthy credit, inexpensive, efficient and controlled } \\
\text { democratically due to the application of cooperative } \\
\text { principles that the Commander Alphonse Desjardins and his } \\
\text { successors never ceased to promote in the very noble goal of } \\
\text { economic emancipation of our working class. Speech by } \\
\text { Paul-Émile Boisvert, manager of the Sherbrooke Regional } \\
\text { Union, during a congress of caisses populaires, } 25^{\text {th }} \text { August } \\
\text { 1950, Revue Desjardins, 16(8), 1950, p. } 187 \text {. }\end{array}$ \\
\hline
\end{tabular}


Figure 1: Evolution of Five Types of Invocation (Number of Quotations/ Year) (three-year moving average to smooth out peaks for easier reading)
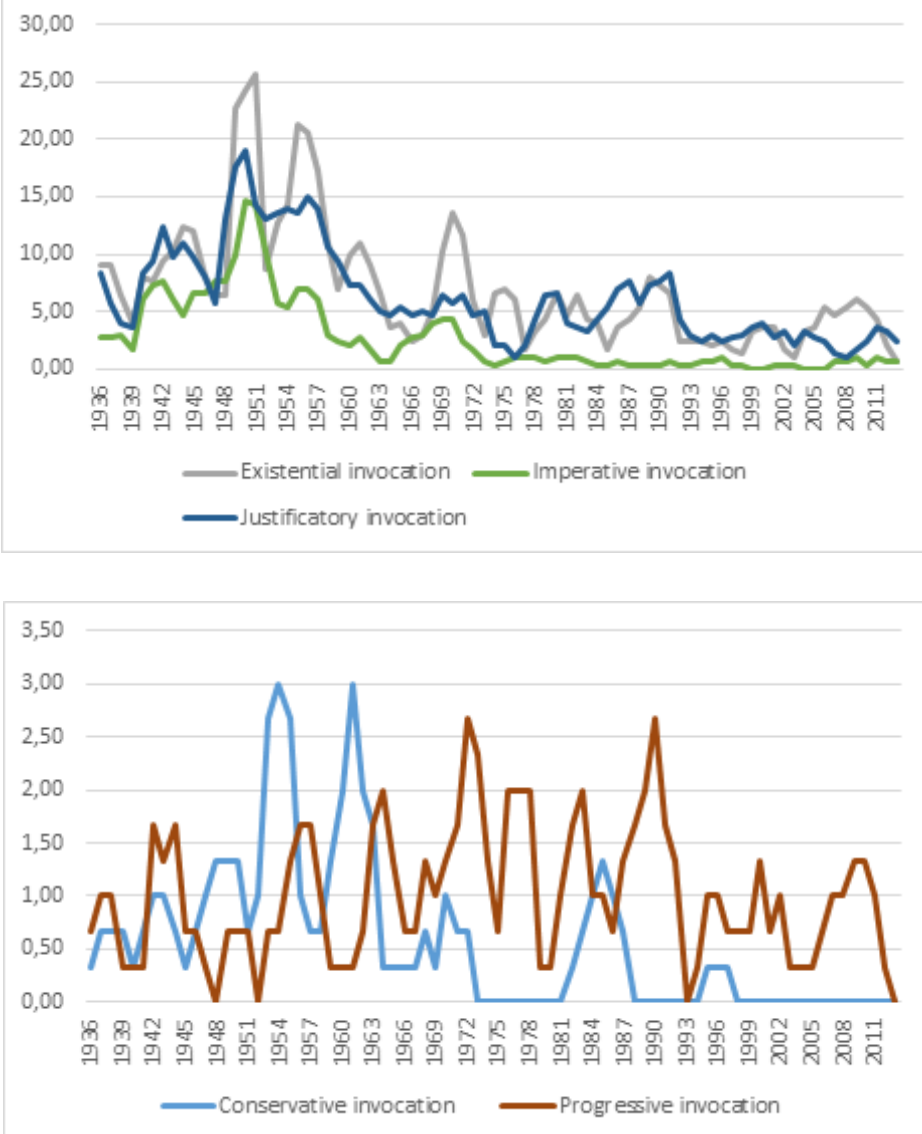
Figure 2: Image on the cover of Revue Desjardins, 74(3), 2008, p.1

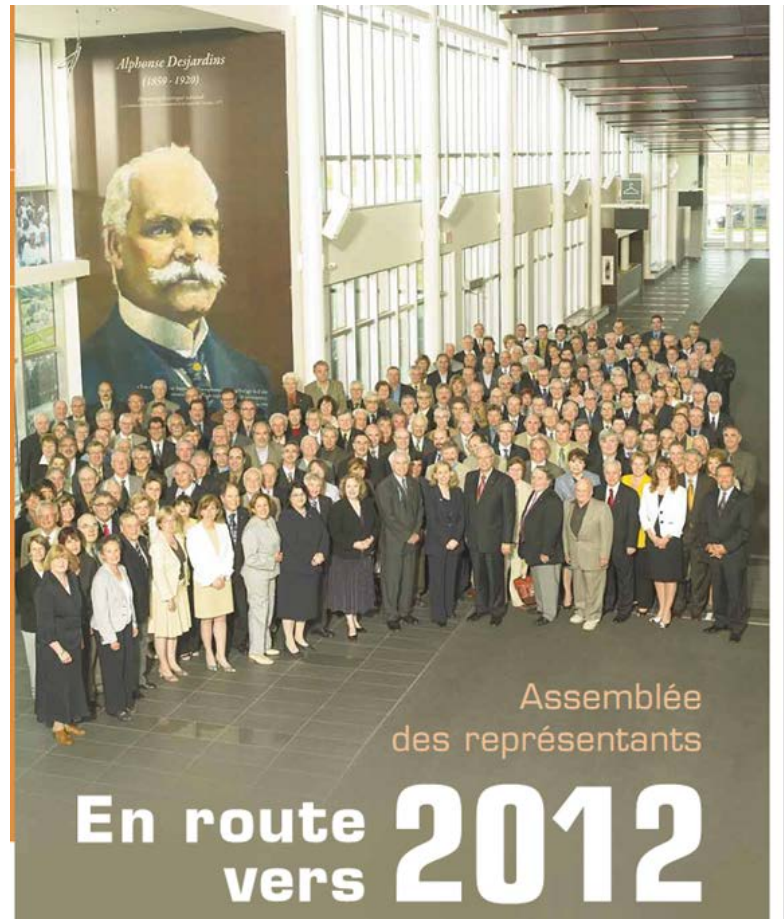

